\title{
The Finnish projector phrase se että as a fixed expression
}

\section{Vatanen, Anna}

John Benjamins

2020-12-10

Vatanen , A , Suomalainen , K \& Laury , R 2020 , The Finnish projector phrase se että as a fixed expression . in R Laury \& T Ono (eds), Fixed Expressions : Building language structure and social action. Pragmatics and Beyond New Series, no. 315 , John Benjamins , Amsterdam , pp. 167-202 . https://doi.org/10.1075/pbns.315.07vat

http://hdl.handle.net/10138/326018

https://doi.org/10.1075/pbns.315.07vat

unspecified

acceptedVersion

Downloaded from Helda, University of Helsinki institutional repository.

This is an electronic reprint of the original article.

This reprint may differ from the original in pagination and typographic detail.

Please cite the original version. 


\title{
The Finnish projector phrase se että as a fixed expression
}

\author{
Anna Vatanen, University of Oulu \\ Karita Suomalainen, University of Turku \\ Ritva Laury, University of Helsinki ${ }^{1}$
}

\begin{abstract}
This chapter shows that the Finnish expression se että 'it (is) that', consisting of a demonstrative followed by a complementizer, is a fixed projective element in talkin-interaction both on its own and with collocating elements. It shares features with projector phrases identified for other languages: it is used both to prepare the addressee for the nature of the upcoming and to underline the upcoming as central to the ongoing interaction. The analysis of se että having grammaticized into a projector phrase is supported by prosodic evidence: the two elements are most often produced as one prosodic word. The findings support the idea that se että emerges in interaction with a fixed form rather than being generated by a syntactic rule.
\end{abstract}

\footnotetext{
${ }^{1}$ Authorship is equally shared. We thank the anonymous referees and the series editor as well as Yoshi Ono for their invaluable comments which have improved our contribution greatly. Remaining shortcomings are of course our responsibility. We are also grateful to the participants of the end symposium of the project "The Question of Units in Language and Interaction" held in Helsinki in 2016, where we first presented this study.
} 


\section{Key words}

conversation analysis, dialect interview, emergence, everyday conversation, Finnish, interactional linguistics, projector phrase, prosodic reduction

\section{Introduction}

This chapter examines the Finnish expression se että 'it (is) that', which consists of the demonstrative se (roughly, 'it') followed by the complementizer että (roughly, 'that'). We suggest that se että is a fixed expression: it is lexically constrained and prosodically reduced. It tends strongly to collocate with a certain set of particles, conjunctions and adverbs, occurs in particular kinds of contexts, and specializes in carrying out certain kinds of actions in ordinary spoken Finnish.

The se että expression can initiate clausal complement constructions but also more complex multi-clausal units both in spoken and written Finnish (see Leino 1999; Suomalainen et al. 2016a, b; Suomalainen et al. in press). Se että can be integrated in another clausal construction, as in (1), but it can also be syntactically independent, as in (2). ${ }^{2}$ In (1), se et $t^{3}$ pystys sillee

\footnotetext{
${ }^{2}$ The key for transcription symbols can be found in the Appendix.

${ }^{3}$ Että is often reduced to $e t$ in spoken language, but not always, as can be seen in example (2) just below.
} 
jammailemaan mukana jossain kappaleessa 'SE ET one could then jam along in some song', functions as a predicate nominal (subject complement) in the copular clause beginning with suurin haave olis 'the biggest dream would be', forming the predicate with the copula olis 'would be'.

(1) [SG123, Arkisyn]

tai niinku suurin haave olis se et pystys sillee or PRT big-SUP dream be-COND-3S G DEM COMP be.able-COND DEM-ADV 'or like the biggest dream would be SE ET one could then'

(0.5) jammailemaan mukana jossain kappaleessa jam-INF-ILL along some-INE piece-INE 'jam along in some song'

In (2), se että and the elements that follow it come after utterance-initial elements that do not include a verb. To put it differently, what comes before se että is not a clause. Therefore, se että is not an argument of any verb or any other element in that utterance.

(2) [SG120, Arkisyn]

niijja sit sitä paitsi viel sit se että,.hh(.) et PTC and then DEM-PAR ADV still then DEM COMP COMP 'yeah and then moreover SE ETTÄ that'

parkettilattialle vaarallisempi (0.3) jos sinne menee sonni tepastamaa parquet-floor-ALL dangerous-COM if DEM-ILL go-3SG bull toddle-INF-ILL '(it is) more dangerous for the parquet floor if a bull goes and trots around there' 
In this study, we focus on cases where se että expressions are syntactically independent, i.e. not integrated in any clausal construction, and occur in the beginning of a turn-constructional unit (henceforth TCU; see Schegloff 1996), as in (2) above. ${ }^{4}$ We suggest that in this position, se että has emerged as a formulaic expression functioning as a projector phrase (see Aijmer 2007, Hopper and Thompson 2008, Günthner 2011, Pekarek Doehler 2011), the nature of which is specified by certain collocating lexico-syntactic elements, a rather fixed prosodic shape and the recurrent interactional work that it is used to accomplish in talk-in-interaction (cf. Pekarek Doehler 2011:106). To show this, we 1) examine the collocational and sequential environments in which se että occurs, 2) discuss the types of actions that are carried out by se että in its contexts of use, and 3) investigate the prosodic erosion of the se että expression in the TCU beginnings. With our study, we aim to contribute to the ongoing discussion on the nature of fixed grammatical constructions (Fillmore 1979; Pawley and Syder 1983; Hopper 1987; Erman and Warren 2000; Scheibman 2000; Corrigan et al. 2009; Bybee 2010): we hope to show that a purely grammatical or even semantic analysis of elements such as se että is not sufficient; linguistic elements such as se että are not generated by the rules of grammar but are ready-made

\footnotetext{
${ }^{4}$ By 'beginning' we mean that se että together with particles and/or adverbs which may precede it come in initial position in a TCU. For more detailed analysis on the "initial" nature of se että, see Section 4 below, especially Section 4.1.
} 
formulas conventionalized for carrying out certain kinds of social actions in certain types of sequential environments.

This chapter is organized as follows. After presenting the background for our study (Section 2) and the data used (Section 3), we examine the recurrent elements that collocate with se että (Section 4). We then move to discuss the interactional functions of the se että turns (Section 5), after which we analyze the prosodic features of the se että expressions (Section 6). Finally, we present our conclusions (Section 7) on the nature of se että as a fixed expression.

\section{Background}

The use of the demonstrative se together with the complementizer että is a well-known phenomenon in grammatical descriptions of Finnish (e.g., Hakulinen et al. 2004:§1145). The generally accepted view, originally proposed by Siro (1968), is that the use of se before an että complement clause is motivated by the need to mark the case that indexes the role of the complement clause in the matrix clause (Siro 1968:203-204). The thinking here is that since complementizers and clauses do not carry case, the demonstrative $s e$ is needed to show how the complement clause is related to 
the main clause and what type of argument it is. Consider the following

example illustrating such use from a written corpus (Leino 1999:28):

(3) $\mathrm{SK}^{5}$

Olen edelleen ylpeä siitä, että osaan lukea, be-1SG still proud DEM-ELA COMP can-1SG read-INF 'I am still proud of (the fact) that I can read'

mutta mitä sillä taidolla loppujen lopuksi tekee.

but WH-PART DEM-ADE skill-ADE end-PL-GEN end-TRA do-3SG

'but what use is that skill in reality/what can (one) do with that skill in the end.'

The adjective $y$ lpe $\ddot{a}$ 'proud' requires that its complement expressing what one is proud of be in the elative case, much as the English proud requires an of or about prepositional phrase for the same purpose. Note that English seems to require a nominal as a complement of the preposition; a mere complement clause does not suffice, as the translation suggests. The idea here then is that se would be required to show that what follows (että osaan lukea 'that I can read') is a complement of ylpeä. Thus, according to Siro (1968), the use of se would be motivated by the need to make the syntax in the clause combination more transparent.

However, Leino (1999:28-29), in his study of se että in standard written Finnish, shows that the majority of the uses of se että cannot be explained

\footnotetext{
${ }^{5}$ The SK index refers to a corpus consisting of all the 1987 issues of a Finnish weekly news magazine, Suomen Kuvalehti. This was one of the corpora used by Leino (1999).
} 
with structural motivations. Leino notes that in some cases, such as (1) above, se is not strictly required, given that the sentence would be grammatical also without $s e$; Leino shows that many predicates that take oblique complements in fact do occur without se in his data. Further, the large majority of että clauses in his data were grammatical objects, and although objects take case in Finnish, only a small minority of the object että clauses occurred with se. Instead of structural motivation, Leino suggests that the use of se että is semantically motivated: certain types of predicates, especially factive verbs, seem to require that their clausal complements take se. Based on this, Leino argues further that the demonstrative pronoun $s e$ turns the että clause into a referring noun phrase that presupposes the existence of its referent (ibid.:42-43), and consequently, the use of the se että construction, as he calls it, has to do with a speaker presenting something as a fact (ibid.:46). In Leino's data, presenting something as a fact is typical in contexts of observations, reasoning, or the expression of evidence for some argument (ibid.:34).

Leino's (1999) data come from standard written Finnish, where se että occurs as a part of clausal constructions, and for such cases, the analysis Leino presents is persuasive. However, in our spoken data, the se että expression seems to have developed functions that cannot fully be explained with a motivation to present something as a fact, even though some of the contexts in which the se että expression occurs in our data - that is, 
observations, reasonings and expressions of evidence for an argument - are rather similar to those in Leino's data. In that sense, our findings are not incompatible with Leino's. However, in the data we examine in this study, the motivation for the use of se että could not be structural, even beyond factors examined by Leino. ${ }^{6}$ This is because in the cases we examine here, se että is not integrated into another clausal construction, and therefore, it does not have a grammatical function in another clause. However, the motivation for the use of se että in our data is not purely semantic either. Instead, we argue that the use of se että in our spoken data has to do with how the expression is related to the organization of actions, turns and TCUs in talk-in-interaction.

In conversation analysis and interactional linguistics, the way actions, turns and turn constructional units are organized is to be understood in terms of the sequential organization of talk (Schegloff 1990, 2007). This moment-bymoment unfolding of talk is largely based on projection, the ability of an individual action or part of it to foreshadow another (Schegloff 1996, Goodwin 2002, Auer 2005). Furthermore, it has been suggested that projection can also be seen as a basis for clause combining. Hopper and Thompson (2008) show that in English and German data, the initial pieces

\footnotetext{
${ }^{6}$ See also Suomalainen, Vatanen, and Laury (in press), where syntactically integrated uses of se että were also analyzed, and where we show that in conversational data, nearly half (48\%) of the uses of se että do not involve integration in a clausal construction, and even in cases that do, the integration can be fairly loose.
} 
of what are commonly considered biclausal constructions (in particular, pseudoclefts, extrapositions, and wenn-clauses) often occur in talk-ininteraction as formulaic expressions that speakers use for the purpose of managing the interaction (see also Pekarek Doehler 2011:104-105). According to Hopper and Thompson (2008:115-116), such formulas typically project certain types of social actions, the grammatical manifestation of which takes different forms, ranging from a single clause to a complex, multi-unit stretch of talk. Based on French and German data, Pekarek Doehler (2011) and Günthner (2011, 2008) have made similar observations, Pekarek Doehler focusing on the French je veux dire 'I want to say', il y a NP 'there's NP' and ce qui/ce que $x$, roughly 'what', which initiates pseudocleft constructions, and Günthner focusing on the German die Sache ist/das Ding ist 'the thing is' construction (see also Aijmer 2007 for the English phrase The thing/fact is). In their studies, Pekarek Doehler (2011) and Günthner $(2011,2008)$ have suggested that such constructions could be called "projector phrases" or "projector constructions", based on the strongly projective properties they have and their sedimentation as discourse organizational devices.

In this chapter, our aim is to extend the aforementioned considerations regarding the nature of projector phrases to yet another language, Finnish. Through our analysis of the Finnish se että expression, we would like to show that there is an interplay between the projective force and the 
fixedness of expressions: when it comes to the Finnish se että, speakers routinely use it in particular contexts for certain purposes, as a result of which it becomes a fixed way of projecting certain actions. We also show that se että is commonly expanded through the use of a particular set of particles, adverbs and grammatical constructions which further serve to project the nature of the upcoming turn or TCU.

\section{Data and methods}

This chapter is based on two data sets from two corpora of spoken Finnish. Our analysis mainly focuses on approximately 15.5 hours of data from the morphosyntactically coded Arkisyn database of conversational Finnish. The data were recorded from the 1990s to the present day and include 16 dyadic and multi-party face-to-face conversations. In our analysis, we compare these present-day conversational data with data from the Corpus of Finnish Dialects (Syntax Archives, University of Turku), which consists of dialect interviews recorded during the 1960s and 1970s with informants born in the late 1800 s or early 1900 s. This dataset consists of 142 recordings from different dialectal areas in Finland. The Corpus of Finnish Dialects is also morphosyntactically coded and available at the Language Bank of Finland. 
For this study, we collected all occurrences of the demonstrative se followed by the complementizer että in our datasets. After this, we went through the data manually and made subset collections of all the occurrences in which se että expression was used as a syntactically rather independent element in the beginning of a TCU (see example 2 above). As a result, we have a collection of altogether 141 instances: 76 instances $^{7}$ from the dataset gathered from the Arkisyn corpus (henceforth Arkisyn) and 65 instances from the dataset gathered from the Corpus of Finnish Dialects (henceforth FinDia).

The older dialect data and the newer conversational data are quite different in nature. Both do represent spoken varieties of Finnish. However, the dialect data consist of interviews in which the linguist making the recording tries to stay as quiet as possible, only prompting the dialect speakers to get them to speak as much as possible. Thus most of these data are monologic and involve narratives, often from the speaker's own life, as well as descriptions of traditions and lifeways of the speaker's community. On the other hand, the newer data were gathered with the needs of conversation analysis in mind. These recordings were made in naturalistic situations which would have taken place even if they had not been recorded. The interaction is as spontaneous as possible, with no attempt to manipulate the

\footnotetext{
${ }^{7}$ For the balance of the data, we excluded 192 cases from the same speaker in approximately 3 hours.
} 
situation, and no preset agenda. For these reasons, some of the differences we found in the use of the expression we are studying may result from differences in the two data sets.

Our method of analysis is Interactional Linguistics (see, e.g., Selting and Couper-Kuhlen 2001; Couper-Kuhlen and Selting 2018) and Conversation Analysis (Sacks, Schegloff, and Jefferson 1974; Sacks 1992; Sidnell and Stivers 2013). Both methods entail detailed, moment-by-moment sequential analysis of the interaction and taking into account the participants' verbal and embodied behavior in the situated, material environment.

\section{Elements collocating with the se että expression}

As a framing and relational element occurring in TCU beginnings (see Schegloff 1996), se että does not commonly stand alone in our data, but rather is accompanied by other elements such as particles of various types (cf. Aijmer 2007:33-37 for the collocational framework of the English The fact is that construction). The collocating elements, together with the se että expression itself, serve to project the upcoming and show how it is related to the prior talk. The collocating elements may occur before the se että expression, or they may, less commonly, intervene between se and että, or follow it. Most commonly the collocating elements are particles or 
conjunctions, but they also include adverbial and even other lexical elements. In addition, the se että expressions may also expand into constructions with clausal elements which serve an existential or other presentative role.

In this section, we will examine the elements that co-occur with se että. We start by looking at elements that commonly precede the se että expression, followed by a discussion of elements which intervene between se and että. After that, we investigate the material that follows the se että expression, both verbal elements as well as non-verbal ones such as pauses and audible breathing. Finally, we discuss the cases that we call "expansions" of se että; that is, existential and other presentative clausal constructions that build on the se että expression and have a similar projecting function as se että does. By looking at the elements collocating with the se että expression we will show how fixed and formulaic expressions are sensitive to their local contexts of use. Furthermore, we propose that the elements that co-occur with se että are not random but rather reflect the different facets of se että as an emergent ${ }^{8}$ device for routinized interactional projection practices. In other words, the collocating elements serve to further specify the nature of the upcoming projected contribution, and thus they serve an important

\footnotetext{
${ }^{8}$ Here, and later in this chapter, we use the term 'emergent' in the sense discussed in Auer and Pfänder (2011:14) and Hopper (2011:26), as an ongoing structuration, the use of expressions in adaptation to the situation at hand; this use of 'emergent' refers to an online phenomenon, as distinct from 'emerging', used to refer to the gradual grammaticization of an expression as it acquires a new function.
} 
intersubjective function, foreshadowing and building the actional import of the turn.

4.1 Elements in the pre-se että position

More commonly than not, se että which occurs in the beginning of a TCU is immediately preceded by other particles or lexical elements. Only in 11 or the 65 uses in our older dialectal data and in 7 of the 76 uses of se että in our conversational data, it occurred in the very beginning of a TCU with nothing preceding it. Most commonly, in 20 cases in our dialect data, se että was preceded only by the particle $m u t(t a)^{9}$ 'but'; in another 12 cases, mutta preceded the expression, but another particle either followed mutta or intervened between se and että. Similarly, in our conversational data, mutta preceded se että by itself ( 7 times) or together with the response particle niin 'so, yeah' or the adverbial sit(te) 'then' (3 times each), and another 7 times with a cluster of other particles (e.g., mut sitte taas seki että 'but then again also SE ETTÄ'), lexical elements, or small clauses. The frequency of mutta occurring with se että in our data reflects the tendency of the expression to occur when the speaker makes a contrast to something in the prior talk (cf. Aijmer 2007:40).

\footnotetext{
${ }^{9}$ Mutta occurs both in its full form and in the reduced form mut in our data. When we discuss the particle as a form, we use the full form, but when we discuss its use in an utterance, we use the form that occurs in that utterance. Same goes for the adverb sit(ten) 'then', the particle nii(n) 'so', and the enclitic -ki(n).
} 
Below is a typical example from our data, where se että is used to bring up its speaker's own stance after conceding her coparticipant's contrasting stance. This is a context in which there is disagreement. It comes from a conversation between two sisters who have been discussing vacation destinations. Jaana has suggested Malta as a possibility and is comparing it favorably against some popular beach vacation destinations such as Rhodes or Madeira; she proposes that Malta is not as spoiled as they are. Tuula then suggests that if one were to travel more, some beach resort might be a possible destination, that she has nothing against them and does not think they are boring.

(4) [SG 437, Arkisyn]

22 Tuula: $\quad$.hh mut et $\uparrow k y l$ siellä niinku, \#v::\#\#armasti et 'but like I'm sure that like'

23 et jos ois hyväl porukalla nin, .hhmh tosi kiva 'if you had good company so .hhmh really nice'

24 käydä syömäs päivällä ja sillä lailla mutta, 'go out to eat during the day and like that but,'

25 Jaana: [mm,

26 Tuula: [.hhhh mut se että >mitä sitte tekee kaikki< but DEM COMP what then do-3SG all 'but SE ETTÄ what would you do then all'

kaikki püivätt. (0.4) tommo[ses pai ${ }^{\circ}$ kas $^{\circ}$.] all day-PL such-INE place-INE 'all day $(0.4)$ in a place like that' 
28 Jaana:

[.hhhh no kato]

'well you see'

29

siinhä mul justiin on ollu kauheen kiva nää

'that's why it's been really nice for me these'

30

kaks, (.) viimest reissuu et mull_on ollu

'last two trips that I have had'

31

Tommi mu ${ }^{\circ} k a\left[n a h^{\circ}\right.$.

'Tommi with me'

32 Tuula:

[nii-i;

'yea:h;'

33

In a turn beginning with the particle mut 'but', which shows a contrast to or incompatibility with the prior (Sorjonen 1989; see also Schiffrin 1987 for the English $b u t$ ), and the complementizer $e t$, which has been analyzed as a device for bringing in a new voice in conversation (Koivisto, Laury and Seppänen 2011), Tuula concedes, using the particle $k y l$, which has been shown to be associated with concessive actions (Hakulinen 2001:191), that if one had good company, it would be fun to go out to eat during the day (1. 22-24). Here she affiliates with Jaana's earlier suggestion of Malta as an interesting destination. The utterance then ends with another use of mutta, already projecting a contrast, and after a short inhalation comes Tuula's main point (1. 26-27), a rhetorical question asking what one would do all day in a place like that. This is the part of Tuula's lengthy turn which is preceded by a use of mut se että. This is a typical context where we find the 
use of $m u t(t a)$ preceding se että. In our data, it is often used in contexts of concession (Couper-Kuhlen and Thompson 2000; Niemi 2015) to bring up the speaker's own stance, forming the gist of her turn or lengthy argument, after conceding another participant's point. After Tuula thus expresses her doubts about the attractiveness of Malta, or beach resorts in general, Jaana then suggests that she has had a good time at beach resorts previously because she has brought along her grandson Tommi.

Consider also the next example (5) from our dialect data, where the use of mutta before se että was even more common, occurring in half (32/64) of the uses of se että in those data. In the example, the interviewee is reminiscing about her own life.

(5) [Kalanti, FinDia]

sit mä (.) mnää käven kahtkymmentviit (.) ko mää meni naimissi. (.) ja nos 'then I was going on twenty-five when I was married and well'

sit (.) mnuи miähen-ol hiuka juappo mut- ei mittä sil taval- et (.) et mä 'then my husband was a bit of a drunkard but not in such a way that I'

oikke stä mittä sil taval saisi sannu really DEM-PAR any-PAR DEM-ADE way-ADE allow-COND say.INF 'really could talk in such a way'

mut se et se ryyppäs kans. (.) kyl hän pä... noi (.)

but DEM COMP DEM drink-PST.3SG also

'but SE ET he also drank. he did da-- work'

viikkon tyäs- ol mut mitä lauvantaisi ain sitt-ot vaa ja.

'during the week but just on Saturdays he then would always drink and.' 
The interviewee tells that she was married at age 25 and then characterizes her husband as somewhat of a drunkard. She then backs out and suggests that her characterization is not quite right and one should not say this. The mut se et construction then forms a contrast with the just prior and is the gist of the telling: her husband did also drink.

The second most frequent particle which occurs before se että in our data is $n i i(n)$ 'so, yeah'. In our conversation corpus, it was used 14 times before se että, two of these just before mutta in concessive turns. Niin, in addition to its use as a clause linker translatable with 'so', is used as a response particle to express affiliation (Sorjonen 2001), as it is in the next example (6). This comes from the same conversation as (4) above. Here the sisters are discussing the use of honey in cooking.

(6) (SG437, Arkisyn)

107 (.)

108 Tuula: siin o vähä eri maku kun sokerissa; 'it has a slightly different taste compared to sugar' 109 Jaana: \#e\# 110 (.)

111 Jaana: $\uparrow n[i i$, 'yeah'

112 Tuula: [et se on parempi, 
'so it is better'

113

(.)

114 Jaana: niin $o[n$.

'yes it is'

115 Tuula:_[semmonea@romi@

'some kind of an aroma'

116 Jaana: nii £(h) ja sitte se että kun mun mielest PTC and then DEM COMP because 1SG-GEN mind-ELA 'yeah $£(h)$ and then SE ETTÄ in my opinion'

$$
\text { se on muka olevinaan terveellisemp }{ }^{\circ} \ddot{a} \ddot{\circ}^{\circ} £ \text {, }
$$

it be.3SGPRT be-PTCP-PL-ESS-POSS healthy-COMP-PAR

'it is supposed to be healthier'

118

119 Tuula: .mthhhhhhhh

120

121 Jaana: mukam[as,

'supposedly'

122 Tuula: [m: $\quad$ ä en koskaan aattele

'I never think about'

123 mitää[n ter]veysasioita

'any health issues'

124 Jaana: [.nff ]

125 Tuula: kun mäl-(.) laitan ruokaa tai sy:ön?

'when I c- (.) cook or eat'

The sisters are in agreement that honey tastes different and better than sugar

(1. 108-114). Tuula then suggests (1.115) that this is due to its aroma. Jaana

affiliates (1. 116) with nii and then, after a brief audible exhalation (cf. 
Sorjonen 2001:118), adds what she marks with se että as an important, additional point (ja sitte 'and then', where ja indexes additivity (see Kalliokoski 1989) and sitte nextness, or even conclusivity (see Hakulinen and Saari 1995)) in favor of the use of honey: it is supposed to be good for you. Interestingly, this point, while it is marked with se että, is also hedged; with mun mielest 'in my opinion' Tuula already anticipates disagreement (Rauniomaa 2008), and with the particle muka 'supposedly' as well as the verbal form olevinaan, which expresses polyphony (Nordlund 2012, 2002; Salminen 2000). It is an index for bringing in another voice, showing that what is being said is not the speaker's own words: with it, Jaana expresses that what she says is hearsay, and possibly not correct. And, as projected, in her next turn, Tuula rejects the importance of healthfulness for cooking and eating.

As we have seen, the most frequent particle occurring before se että in both of our sets of data, mutta 'but', marks the upcoming as something that contrasts with prior talk, and together with se että, projects more talk which contains the gist of the speaker's turn and expresses her own stance (e.g., Du Bois and Kärkkäinen 2012) or main argument regarding the matter at hand. The second most frequently occurring particle just before se että is nii( $n)$ 'so'; 'yeah'), which is used to affiliate with the prior turn. Other particles can also occur between the initial particles niin or mutta and se että (example 6). As we have seen, turns in which se että is preceded with niin 
(example 6) and mutta (examples 4 and 5) can also disagree and disaffiliate with the prior turn, or project disagreement.

4.2 Elements in the mid-se että position

As already mentioned, in our data, se että expressions are rather formulaic and allow only little variation. As Section 4.1 showed, it is quite common for something to precede se että. It is also possible but less frequent in our data that something appears between se and että. This happens in 30 out of the 141 cases: in 17 out of 76 in the Arkisyn dataset and 13 out of 65 in the FinDia dataset. The material between the two constituents of the se että expression can mainly be divided in two groups: 1) the enclitic additive particle -ki(n) (seki(n) että 'also SE ETTÄ’), or 2) a stand-alone particle (se [particle] että).

The Finnish enclitic particle -kin is the most common individual element between se and että in our Arkisyn dataset; it occurs in 7 out of 17 cases with an element in the mid-se että position. The enclitic particle -kin typically marks the element it is attached to as additive (Vilkuna 1984; see also Hakulinen et al. 2004: $\$ 842,1097)$, and this is also the meaning it carries in the se että cases it occurs in, as in (7) below. The participants are three young adults, Kaisa, Masa and Toini, who know each other through congregational activities. Before (7), the participants have been talking 
about apostolicity and discussed who can be considered to be an apostle.

There has been a longer sequence in which Kaisa has reported to the others what a certain preacher has said and explained how those words have affected her thinking. Just before this extract, she has told how she has come to realize that the post of apostle still exists today. The se että expression accompanied by the enclitic particle -kin occurs in line 5 in Kaisa's turn in which she goes on to report that the preacher also said that even though Paul was not an apostle according to certain definitions, he can still be seen as an apostle from a wider perspective.

(7) (Arkisyn, SG440)

1 Kaisa: tai sillee et, (0.2) niinku, (0.4) avautunus silmät ja 'or kinda like (0.2) like (0.4) (my) eyes were opened and'

$2 \quad$ niinku se tavallaan se vir [ka niinkut tunnustettu ja nostet ${ }^{\circ}$ tuh $^{\circ}$. 'like it kinda the post (of apostle) is like recognized and elevated.'

3 Toini: $\quad[\mathrm{mm}$,

$4 \quad(0.4)$

5 Kaisa: mut se ki että miten niinkuh,.$h h(0.2)$

but DEM-CLI COMP how like

'but also SE ETTÄ how like'

6 se sano, (.) just, (.) ku mä en ollus

3SG say.PST-3SG exactly when $1 \mathrm{SG}$ NEG-1SG be-CONNEG

'he said, exactly, because I hadn't'

7 sitä aikasemmin tajunnu että DEM-PART early-COMP realize-PTCP COMP 'realized it earlier that'

$8 \quad$ eihäm $\uparrow$ Paavalikaa esimerkiks eihän se oo, (0.4) 
'Paul for example is not, he is not,'

sehän ei oo tavallaan niinkus se sama apostoli ku, .hh (0.2)

'he's not kinda the same apostle like,'

10 ne oli ne, (0.4) opetus[lapset ka- koska sehän niink[u, 'they were those, (0.4) disciples, because he like,'

11 Toini:

[nii.

[nii, 'yeah.' 'yeah,'

In line 5, Kaisa introduces a new perspective with the se että expression. Se että is preceded by the particle mut (cf. examples 4 and 5 in Section 4.1), showing that what Kaisa is about to say provides a shift in perspective compared to preceding talk. The enclitic particle $-k i$ attached to the se että expression links the turn to earlier content of the conversation: it shows that the perspective introduced in Kaisa's upcoming turn (1. 5-10) is additional information in regard to what has been said earlier. If we look at the content the se että expression is projecting, we can see that it actually involves new information. Kaisa is both reporting what the preacher said, but also assessing it by providing her own reflections regarding the preacher's words. In this example, the role of the se että expression is to tie the upcoming turn to the earlier content of the conversation, but also to make space for a change of perspective in the ongoing sequence. This is reflected in the collocating elements, the contrastive particle mut and the enclitic particle $-k i$.

Interestingly, we have no cases of the enclitic particle -kin occurring with se että in our FinDia dataset. This might be due to the nature of the two 
datasets we are using. In the Arkisyn dataset, the seki(n) että expressions add information or a new perspective to the ongoing conversation. Since the FinDia dataset consists of interviews, the turn-taking is very different there; the interviewees have rather long turns that are almost monologic, while the interviewers are expected to listen and let the interviewee speak. Because of this, contexts where one participant would add something to the other participant's earlier turn or turns do not really occur.

In addition to enclitic particle-kin, stand-alone particles are also common elements in the mid-se että position in our data. They occur both in the Arkisyn and the FinDia datasets. The particles that we have in the mid-se että slot are kans ('as well'), justii ('exactly'), viel ('more; also'), and vaan ('just'). All of these are focus particles, which add an extra tone to the clause or the turn they occur in, making the whole clause or turn or some part of it focal (see Hakulinen et al. 2004:§839). When they occur in the se että expression, these particles explicitly frame the material that follows the se että expression in a certain way and thus give the recipient(s) a more finegrained description of the content that follows the se että expression (cf. Aijmer 2007:36).

One of the particles that occurs as a part of the se että expression in both the Arkisyn as well as FinDia datasets is $v a a(n)$ 'just; no more than, nothing 
but $^{\prime 10}$. Vaan has been analyzed as a discourse marker that implies that the content of the utterance is unexpected and zooms in on what is of primary importance in the course of events (Duvallon and Peltola 2017a and b). With vaan, speakers can mark the utterance as contrastive to earlier content and provide a specification, an alternative explanation or a new perspective to the speech situation (Duvallon and Peltola 2017b:514-515, 518). Furthermore, in storytelling sequences, the particle vaan typically signals the climax or culmination of the story (ibid.:520). As a part of se että expressions with a mid-se että positioned element, vaan has similar functions: in our data, what follows the se vaan että expression is put in contrast to what has been said earlier. In this sense se vaan että cases resemble the mut se että cases (see Section 4.1). However, the difference between the two is that in the mut se että cases, the adversative dimension is more foregrounded, while the se vaan että cases are more prospectively oriented. In se vaan että, the force-dynamic focus is on the following content that expresses what is essential from the speaker's viewpoint in the situation under consideration (cf. Duvallon and Peltola 2017b:21).

Interestingly, we also have some cases in our data where both mutta and vaan occur as a part of the se että expression. Consider example (8), where

\footnotetext{
${ }^{10}$ Finnish dictionaries and grammars (e.g. NS, Hakulinen 2004:\$828) classify vaan as an adversative coordinating conjunction which also has (other) particle functions. It is thought to have developed from an adverb meaning 'steadily' (see Duvallon and Peltola 2017a:21, who also note that the lexical root of vaan is not transparent to a modern Finnish speaker).
} 
se että is accompanied by both the pre-positioned mutta and the mid-

positioned vaan (here a dialectal variant vaen). This example shows that a speaker can express both a contrast with the preceding with mutta as well as prospectively marking with vaan the culmination of the story in the same utterance. Just before the extract in (8), the informant, whose father has worked as a forest ranger, has told the interviewer how people sometimes cut down trees from state forests without permission in order to get lumber for free. In (8), the informant moves on to tell what the consequences of such action were.

(8) (Yli-Kiiminki, FinDia)

1 ei net sitä semmosena minään suurempana rikoksena pitäny (.) 'they didn't consider it to be a serious crime (.)'

2 sakotti ne kyllä

'they did give fines'

3 mutta se vaen että ei siittä linnahaj joutunuk koskaan- että(.) but DEM just COMP NEG.3SG prison-ILL end.up-PTCP ever COMP 'but SE just ETTÄ one never ended up in prison because of it (.)'

4 minäaenakaan en kuullu ett- ois joutunum 1SG at.least NEG-1SG hear-PTCP COMP be.3SG-COND end.up-PTCP 'at least I didn't hear that somebody would have ended up (in prison)'

In the extract, mutta se vaen että is used to create contrast in its context: even though there were some legal consequences of cutting down stateowned trees without permission - one had to pay a fine for it - people did not end up in prison for stealing wood. The contrastive function is 
highlighted by the preceding mutta (mutta se vaen että). The mid-positioned vaen here is mainly used to project and zoom in to the content of line 3 , the main point of the story, which is that even though stealing lumber should have led to severe legal consequences, that is, jail time, most of the time it actually did not. ${ }^{11}$

As the examples in this section show, the linguistic element that is in the mid-se että position explicitly specifies to the recipient how the turn that the se että expression is projecting should be interpreted. Their local function is thus to foreshadow, even more than in the case of the preceding elements. Furthermore, as was the case with the preceding elements (see Section 4.1), the elements in the mid-se että position can also highlight certain functions of se että expression in its context, such as adding to what has been said before (example 7) or creating contrast while redirecting the discourse (example 8).

4.3 Elements in the post-se että position

This section examines the material that follows se että. Our focus will be on the conjunctions that appear right after se että, such as $k u(n)$ 'because; since;

11 As noted, Duvallon and Peltola (2017b) show that the discourse marker vaan marks what is of primary importance in the course of events. The se että expression seems to have a similar function in our data, as will be shown in Section 5 below. 
when', et(tä) 'that' and jos 'if', as well as the possible pauses and audible breathing. In other words, here we also keep our structural focus on the elements in the 'beginning' part of the TCU (i.e., on the framing material). Out of the 76 cases in our Arkisyn collection, 25 cases include at least one of these elements in the post-se että position. ${ }^{12}$ Among these 25 cases there are 11 instances of $k u(n)$ 'because; since; when', 10 instances of et(tä) 'that', 4 instances of jos 'if', and 3 instances of niinku 'like'. In 7 of the cases there is audible breathing right after se että, and in 6 cases there is a noticeable pause after it. At least some of these elements frame the upcoming content in a certain fashion (e.g., jos, $k u(n))$, helping the co-participant anticipate the nature of the upcoming (cf. Pekarek Doehler 2011:140). On the other hand, some of the elements seem to be related to the speaker processing the upcoming content of his/her turn (e.g., niinku, audible breathing) (cf. Günthner 2011:18-19). In addition, it is interesting that the se että expression may also be followed by a second et(tä) element. Let us now analyze some examples from our data. In the first one, the two middle-aged sisters (examples 4 and 6, and 14 below) are talking about eating out. The se että (or actually seki että) expression, followed by a pause and jos 'if', occurs in line 11.

\footnotetext{
${ }^{12}$ The FinDia corpus also includes cases like this, but they are fewer in number: there are two instances of se että et(tä), two instances of se että ni(i), and one instance of se että kun and se että jos each. These cases are qualitatively similar to the present-day instances; however, we will not present any of them here.
} 
(9) (SG 438, Arkisyn)

01 Jaana: ku, .nfffff mä en, (0.2) 〈 en kerta kaikkiaan> 'because, .nfffff I don't (0.2) I don't at all'

02 tajuu sitä että, hhhh et miks pitää 'understand the thing that .hhhh that why one has to'

03 syödä ulko\#ilmass[a\#.]

'eat in the open air.'

04 Tuula: $\quad[m] m[\because:$

05 Jaana: $[\uparrow k y l,(0.2) \uparrow s e,()$. 'sure, (0.2) it, (.)'

$06 \quad \uparrow$ no se oli justii et sillon kun me oltiin 'well it was exactly, that when we were'

07 siel Vakkulanrannassa ni jollain tämmösel 'there in Vakkulanranta on some kind of'

08 pịk\#nikil[lä mut\# $\left.{ }^{\circ} t^{\circ},\right]$ 'picnic but so'

09 Tuula:

$$
\begin{gathered}
\text { [.hhhh ] se on, (.) } v \text {-se on } \\
\text { DEM be.3SG DEM be.3SG } \\
\text { hhhh 'it is (.) a b-it is' }
\end{gathered}
$$

10

pikkasen eri juttu mutta, .hh ylipäätään

a.bit different thing but in.general

'a bit different thing but, hh in general'

seki että, (0.4) jos menee niinkun \#uи\#

DEM-CLI COMP if go-3SG PRT

'also SE ETTÄ (0.4) if one goes like uhm'

12

kesällä ulos syömään ni mä en tykkää summer-ADE out eat-INF-ILL so 1SG NEG-1SG like 'in the summer to eat out so I don't like'

syödä terassilla $u l^{\circ} \mathrm{kona}^{\circ}$.

eat terrace-ADE out

'to eat out on a terrace.' 
14 Jaana: $\uparrow j o o$ e $\underline{\text { it. }}$.

PRT NEG

'yeah no.'

This fragment begins with Jaana's negative assessment about eating in the open air (lines 1-3). After Tuula's response particle $m m$ (line 4), Jaana presents an exception to her strong opinion: having a picnic is fine (lines 58). In the beginning of the turn that is to include the se että expression to be analyzed (from line 9 on), Tuula first agrees with Jaana's previous turn and then goes on by presenting a contrast, initiated with the conjunction mutta 'but' (see analysis of examples 4-5 above; see also examples 7-8) and the adverb ylipäätään 'in general'. These elements are followed by seki että, a pause and a clause combination initiated with the conditional conjunction jos: 'if one goes like uhm in the summer to eat out so I don't like to eat out on a terrace'. This part of Tuula's utterance is presented as a contrasting and additional point (note the additive clitic $-k i$; see the analysis of example 7 above) to the line of argumentation initiated by her co-participant, bringing the topic to a more general level with the help of the adverb ylipäätään 'in general'. So, here, in addition to the interactional work accomplished with the other elements surrounding se että, also the following conjunction jos serves to frame the upcoming content in a certain fashion, guiding the recipient's interpretation of the unfolding turn. 
Interestingly, se että can also be followed by the complementizer et(tä), in

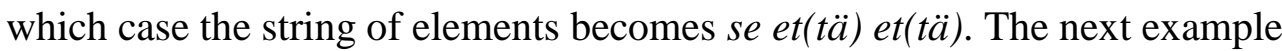
is from a situation where friends are discussing issues related to faith and religion (see example 7 from the same conversation). Here Kaisa reports on what she has heard a person called Håkan to say in relation to events in their own congregation. The fact that Kaisa produces her telling on the fly, in other words, that her utterance emerges online (see, e.g. Auer and Pfänder 2011:14; Hopper 2011:26; see also fn. 7), is rather clear here, and this also is the context where the se että expression occurs (line 6):

(10) $(2.37$, SG 440)

01 Kaisa: ja sillee että .hhhh niinkuh Hookkankis sano 'and so that .hhhh like also Håkan said'

02 että se, (0.2) tai $\uparrow$ sitä se sano et kuh, .hhhh 'that it, (0.2) or this was what he said that as, .hhhh'

03 tavallaaj just toi että mitä meiänkis seurakunnas 'in a way exactly the thing that is also happening in our'

04 tapahtuu tai silleem mitev vahvastin niink\#u:\#, 'congregation or like how strongly like,'

05 (0.6) Jümalan niinku, (1.0) läsnäolo on tai sillee God-GEN PRT presence be.3SG or PRT (0.6) 'God's like, (1.0) presence is or kind of'

06 siellä nis se että, (0.4) että sịtä just ku ei DEM-LOC PRT DEM COMP COMP DEM-PAR PRT as NEG 'there so SE ETT $\ddot{A},(0.4)$ ETT $\ddot{A} /$ that exactly the thing that it'

se oov vaaj joku:; (0.4) vaan niinku, (.) et sitä
DEM be.CONNEG just some CONJ PRT COMP DEM-PAR
'is not just some (0.4) but like (.) that it'


10 Toini: $m m$,

The se että expression here initiates a further point in the speaker's lengthy turn. First Kaisa frames her talk as a report on what "Håkan" had said (line 1) and specifies that it concerns what happens in their congregation (lines 34): there is a strong presence of God (lines 4-5). After this, she produces the se että expression, prefacing it with $n i(s)$ 'so', which also indicates that she is now getting to a point: that the participants are 'part of something bigger' (line 9) that is present 'around the world' (lines 7-8). What the point actually is emerges gradually; there are several signs of online planning, such as pauses and particles associated with planning, processing and reformulation (niinku 'like', sillee 'that way; like that', tai 'or'). Also right after se että (line 6) there is a 0.4 second pause (this is not rare in our data; see also examples 3 and 9 above). Interestingly enough, the element following the pause is another instance of että (which is not rare in our data either: 10 of the 25 se että $X$ cases in our Arkisyn corpus are like this). We suggest that both the pause and the second että point to the fixedness and crystallization of se että as an expression: What follows se että is often like here - a longish telling or report that may require significant processing 
effort from the speaker, which may result in pauses, audible inhaling, word searches, repetitions and restarts during the turn - as happens here.

Furthermore, and even more importantly, as se että seems to have developed into a single unit with distinct characteristics and functions, the elements that it consists of (se and että) seem to have lost (at least some of) their original grammatical meaning and use. This is perhaps even more true of the että element, as quite often there is another että after the first one (as in example 10 above). In this way, the se että expression seems to have lost at least some of its internal structure: its että element is no longer functioning as a complementizer, witnessed by the fact that the speaker adds a new complementizer että. The prosodic production of the se että as one single unit (see Section 6 below) also points to this direction. Only after having produced the se että expression, the speaker begins to produce the continuation of his/her turn in more detail.

In this way, se että seems to behave as an "intersubjective placeholder": it signals the recipients that there is something coming, and with the help of this expression, the speaker can still process the point $\mathrm{s} / \mathrm{he}$ is about to verbalize (cf. Pekarek Doehler 2011:129). This is among the reasons why we see se että as a projective device, pointing to the nature of the upcoming content. We argue that the contexts in which se että frequently occurs have contributed and contribute to what can be expected to occur after it; as a result, se että has developed an interactional function that is more than the 
sum of its parts. In addition, the other elements surrounding se että also indicate the direction the speaker's turn is taking.

4.4 Expansions of the se että expression

In our data, we also have cases where se että belongs to an existential or other presentative construction. We consider these semantically rather empty means that frame the se että expression as expansions of it. Typically, these expansions are clausal constructions in which the predicate verb is olla ("to be'). Consider the following examples. In (11), se että and the material that follows it is a complement of an existential construction siin on 'there is' ( siin on seki että 'there is also SE ETTÄ'). In (12), on the other hand, se että is framed by a predicative clause se oj just 'it is exactly' (se oj just se et 'it is exactly SE ET'):

(11) (Arkisyn, SG437)

Tuula: (nii) kai siin on seki että, (0.4).nff et lapsella PRT ADV DEM.LOC be.3sg DEM-CLI COMP COMP child-ADE aina, (0.8) mt hirveitä vaatimuksii; (0.4) ja always terrible-PL-PAR demand-PL-PAR and edellytyksii $\underline{a ̈ i t i a ̈ ~ k o h t a a n, ~}$ precondition-PL-PAR mom-PAR towards 'yeah I guess there is also SE ETTÄ, (0.4) that a child always (0.8) has terrible demands and preconditions for the mother.' 
(12) (Arkisyn, SG120)

Lotta: se oj just se et millom mie lue sitä

DEM be.3SG exactly DEM COMP when 1SG read DEM-PAR

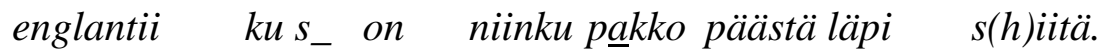

English-PAR as DEM be.3SG PRT must get through DEM-ELA

'it is exactly SE ET when do I study English as it is like a must to get through it.'

Example (11) comes from the same conversation as (4), (6) and (9). The participants are two sisters who are discussing everyday matters, in this particular context the way children behave towards their parents. Example (12) is an extract from a conversation between three high-school girls who are doing their homework together. Interestingly, in both examples, the clausal expansions of se että are projecting a statement or some kind of inference that the speaker makes based on the earlier content of the conversation.

As examples (11) and (12) show, the lexical content in the expansions of the se että expressions is quite often semantically relatively empty. However, in our data, we have some examples of expansions of se että that include a lexical item that somehow describes or specifies the content that the expanded se että expression projects. These kinds of expansions typically have the structure of a predicative clause: the descriptive item is located in the syntactic position of subject, whereas se että and what follows it can be considered to function in the role of the predicate nominal. We demonstrate 
this with (13) below. In the extract, two female friends are celebrating New Year's Eve together and discussing a recent novel that had received an important literary prize. Their mutual complaint is that the novel lacks a coherent theme and a clear main character. The se että expression occurs in Tarja's turn (1. 8) in which she is describing what the point of the novel apparently was.

(13) (Arkisyn, SG 398)

1 Tarja: [mjoo si-joo s[e oli semmone] [tilkkutäkki=joo] 'myeah it- yeah it was a kind of a patchwork quilt yeah'

2 Kati: [ [.hhhh siin oli] 〈\#I:[:i\#var \#o:〉] .hhhh 'there was Iivar'

3 Kati: $\quad{ }^{\circ} \# m\left[:^{\circ}\right.$ mitäs siin oli vielä muita niitä 'w- what were still some of the others'

4 Tarja: $\quad[\mathrm{mm}$,

5 Kati: $\quad=. h h h$ \#e:e\#- $\uparrow$ et se ei ollu niinku oikeen $\downarrow$ kenenkään. .hhh 's- so that it wasn't really anyone's.'

6 (0.6)

7 Tarja: ${ }^{\circ} n^{\circ} e i \quad$ se $\quad$ kyl ilmeisesti ollu siNEG.3SG DEM PTC apparently be.PST.CONNEG 'it apparently wasn't th-'

8 ajatuskin vaan oli se että niinkun, thought-CLT PTC be.PST.3SG DEM COMP like 'the idea just was SE ETTÄ like'

$9 \quad(1.0)$

10 Tarja: hahmottaa [ kok]o maailman m(h)eno [he het $e(h) n$ characterize-INF whole world-GEN go.NOM NEG-1SG 'to characterize the nature of the whole world' 
11 Kati: $\begin{aligned} & {[j o o,]} \\ & \text { 'yeah' }\end{aligned}$

In this example, the descriptive item is ajatus ('idea'), which is accompanied by the enclitic particle -kin that links the turn to earlier content of the conversation (see Hakulinen et al.:§843; see also examples 7 and 9). The se että expression occurs at a point where Tarja describes the book by interpreting what the intentions of the writer were. The structure of which se että is part, ajatuskin vaan oli se että 'the idea just was SE ETTÄ', projects further talk to come, and the item ajatus 'idea' has the role of a specifier: it sets up a certain frame of interpretation for the following talk for the interlocutor, Kati. Expansions of the se että expression can also have postelements, similarly to the se että expressions with other collocating elements (Sections 4.1-4.3): in this example, there is the particle niinkun ('like') in the post-se että position (see Section 4.3). The whole extended expression is followed by a rather lengthy pause (1.9) before the material that se että projects is actually uttered.

In their contexts of use, the expansions of the se että expression function as projector phrases rather similar to the bare se että or the se että expressions with other collocating elements. However, in our data, the difference between the independent se että and the clausal extensions of se että is that the latter seem to be more closely tied to the earlier content of the sequence, 
even prosodically, as in (13), where there is a lengthy pause after se että and the particle that follows it, and thus get their projective motivation from something that has been brought up earlier in the discussion - either explicitly or implicitly. In the expansions of se että, the connection to what has been said earlier is made explicit with the elements occurring in the beginning of the clausal expansion; typical elements occurring in this position are demonstratives (see ex. 11-12) or lexical items (see ex. 13) that refer to something already introduced into discourse. In this sense, the information that follows the expansion of se että is projected as specifying something that has just been said; either contrastively or in an agreeing manner. And, as the information that the se että expansions are projecting is often a lengthy turn or a stretch of talk, the clausal elements can be interpreted to link the subsequent talk explicitly to a certain matter in the preceding conversational context, thus guiding the recipient's attention to what is central in the following TCU or TCUs.

4.5 Collocating elements: summary and discussion

In this section, we have examined the elements that co-occur with se että in our data. We have analyzed elements in the pre-, mid- and post-se että position and investigated the clausal expansions of se että. By doing this, we have shown that even an expression as fixed as se että does not exist in a vacuum but is sensitive to its local contexts of use. Conversely, the contexts 
of occurrence for the se että expression are not random either, but themselves manifest a degree of formulaicity arising from the uses that the fixed expression itself is put to in interaction, as also suggested for the elements examined in the other studies in this volume. On the basis of our analysis of se että, we suggest that fixedness of a certain expression may spread to the surrounding lexical and actional context, as a result of which the association of grammatical formats and the actions they serve becomes even closer and even more fixed (see especially Endo and Yokomori, this volume). In other words, fixed expressions may gather around them even more formulaicity, as speakers routinely use them in certain contexts. This process could be seen as spreading of systematicity to a level beyond the formulaic expression itself, also involving grammar as well as interaction.

The frequency with which collocating elements occur with the se että expression of course raises the issue of how fixed the expression after all is. For one thing, it is more common for se että to be preceded by other elements rather than having something intervene between its two parts; this shows that se että forms rather a fixed unit. On the other hand, the collocating elements are not random; certain particles and conjunctions occur very commonly with se että. This has to do with the core functions of se että, which will be presented in the following section in more detail. For example, the conjunction mut(ta) 'but' occurs very commonly with se että, and is connected with the core function of the expression: what follows it 
often forms a contrast with what has been said just prior. Likewise, the clitic -kin 'also' commonly intervenes between se and että. This, again, has to do with the fact that se että expressions commonly frame additional arguments in an ongoing discussion. In this sense, the preceding and intervening elements are also to some degree formulaic and connected with the actions and practices that this expression has become associated with. And, since se että is - we argue - a projector phrase, it is followed by further talk that is not random either but follows certain patterns connected with the general functions of se että. In the next Section 5, we move on to deal with these functions in more detail.

\section{Interactional functions of the se että expression}

As suggested in the analysis of the examples in Section 4, se että typically emerges in certain interactional contexts for specific purposes. In this section, we will take a deeper look into the functions of the se että expressions in their contexts of use. We show that in the interactionally relatively fixed contexts se että occurs in, it emerges as a projector phrase that is routinely used in the context of specific social actions.

In our Arkisyn data, se että expressions typically occur in contexts where the speaker is expressing her knowledge, understanding and stance. Typical 
activities which involve the fixed se että expressions are storytelling, assessment, informing, and asserting. The following excerpt (14) is an example of the se että expression in its typical context of use. The example comes from a conversation among young women friends who have been discussing hair salons, their recent haircuts and their satisfaction with them. In (14), se että occurs TCU-initially in Susa's statement (1. 5), in a turn whose purpose is to provide reasoning for the speaker's assessment.

(14) (SG151, Arkisyn)

1 Susa: et $\uparrow$ nyt mie niinku käsitän sen tai siis 'so now I kind of understand it or I mean'

2 sillee et vaik mie o îte monta kertaa kans sanonu 'like although I have said many times myself'

3 sitä et ei viittis nii hirveesti \#kampaajaa laittaa rahaa\#, 'that it's not worth spending a lot of money on a hairdresser'

4 Jossu: $m m$ ?

5 Susa: hh mut se et jos sit laittaa vähärahaa ja sit siit but DEM COMP if then put-3SG little money-PAR and then DEM-ELA '.hh but SE ET if you spend only a little money and then'

6 tukast tulee hirvee ni sekää ei o kiva. hair-ELA come-3SG terrible so DEM-CLT NEG.3SG be-CONNEG nice 'your hair comes out terrible then that's not nice either.'

7 Jossu: $\left[{ }^{\circ} e: i^{\circ}\right.$, NEG.3SG

'(no it) isn't'

Earlier in the discussion, Susa has brought up the high cost of haircuts, and just before this example, she has mentioned that she has had two cuts in her 
life that she really has not liked and has not been comfortable with. In lines $1-3$, she then acknowledges that spending a lot of money on haircuts is not worth it; in this part of the turn, the particle vaik 'although' already projects a contrasting point to follow. After Jossu's response particle $m m$ ? (1. 4), Susa then brings up the gist or main point of her rather lengthy and complex multi-unit turn: it is not too good to spend only a little money at the hair salon either if one's hair comes out terrible (1. 5-6). This TCU is initiated by a contrastive $m u t$ 'but' followed by se että. Here se että occurs in its typical context of bringing up the main point of a lengthy or complex turn. Often the se että turn is preceded by a concession which aligns with something someone else has said (see example 4), or just an acknowledgement of a contrastive stance, as here. This is reminiscent of the triadic statementacknowledgment/concession-restatement pattern discussed by Antaki and Wetherell (1999) and Lindström and Londen (2013). However, we do not quite have such a pattern in this case. ${ }^{13}$ The se että after a concession is often preceded by a contrastive element (such as mut here; see also example 15 below).

Since the FinDia dataset is originally not gathered for conversational research and is rather monologic in nature (see Section 3), it is not possible

\footnotetext{
${ }^{13}$ This is not a full three-part sequence here of the kind discussed by Antaki and Wetherell (1999) and Lindström and Londen (2013). Although lines 2-3 can be said to form a concession or acknowledgement, the claim in lines 5-6 is not a restatement of anything that the speaker would already have said, since line 1 does not express what she has understood.
} 
to look at the actions of the se että turns in the same way as in the Arkisyn data. However, in the dialectal data as well, se että expressions typically occur in storytelling, and especially when the speaker is assessing particular circumstances and then adds either new or contrastive information to the ongoing telling. The following example (15) is a good demonstration of the way se että expression, here accompanied by the particle mut ('but'), functions in the old dialect data. The topic here is harvesting. The interviewer asks a question that implicates that it was slow to harvest with a sickle (1. 1). In his responsive turn in lines $2-4$, the informant concedes the slowness of using a sickle, but, using the se että expression (1. 2), adds that that is how the things were back then, and harvesting with a sickle required skill and practice.

(15) (Lappi TL, FinDia)

1 Interviewer: eik se ollu vähä hidasta ku sirpil.... 'wasn't it a bit slow when (you did it) with a sickle...'

2 Informant: no k... kyl maarse hirasta on mut se et... (.) PTC PTC PTC DEM slow-PAR be.3SG but DEM COMP 'well for sure it is slow, but SE ETTÄ (.)'

3 semmos se sitt-ol se (.) tai... such-INE DEM then be.PST.3SG DEM or 'that is how it was then (.) or...' 
As was seen in the examples above, in its interactional context, se että typically continues the sequence underway: the turn containing the se että expression may function as a complement, contrast or addition to something the speaker has mentioned earlier (see ex. 14), or to present a new perspective on or reformulation of something that the current speaker or another participant has said earlier (see ex. 15). This is especially typical of cases where the se että expression is preceded by particles such as mutta 'but' or tai 'or' (see Section 4.3, ex. 10).

Although, as we have shown, the se että expression often precedes a point that contrasts with something said just prior, it can also be used to frame a point in support of the preceding discussion. In example (16) from a family dinner conversation, the participants have been lamenting the conflicting demands on students to focus on their studies while also having to earn a living to augment the insufficient stipends they receive and also to get work experience for the benefit of their future careers.

(16) (SG441, Arkisyn)

17 Liisa: .hh ja sit taas toisaalt myös se että and then again on.the.other.hand also DEM COMP '.hh and then on the other hand also SE ETTÄ'

18 ihan sama vaikka opintotukee nostettaiski quite same even.if study.support-PAR raise-PASS-COND-CLT 'it makes no difference even if student stipends were to be raised'

19 ja opiskelijat pärjäis, 
and student-PL cope-COND-3SG

'and students could manage'

20

$(0.4)$

21 Kasperi: ${ }^{\circ} \mathrm{mm}$,

22 Liisa: niinku opintotuella,

'with the student stipend'

23

(0.4)

24 Liisa: $\quad>n i$ sit< on $\uparrow \underline{e}$ delleen se puute että niil ei

'so then there's still the problem that they don't'

25

oo työkoke[musta.

'have work experience.'

26 Kasperi: [\#mm.\#

In (16), Liisa's turn beginning in line 17 serves to amplify and continue the point that has already been made, but also adds a new perspective: even if the student stipends were raised enough so that students could manage without working, they would then lack any work experience. Here, we can see that the particles preceding se että also serve to project the import of Liisa's upcoming TCU. Both ja 'and' as well as myös 'also' have an additive meaning and show that what follows is an additional argument in support of what has already been said (on ja, see Kalliokoski 1989). Sit 'then', coming right after $j a$ 'and', expresses that the upcoming is a conclusion (Hakulinen and Saari 1995; see also example 6 above), while taas toisaalta 'again on the other hand' shows that what follows offers a new perspective. In this example, the presentation of the new perspective 
works to provide a background for the upcoming stance/conclusion (1. 2425), which in turn aligns with the perspective already brought up earlier in the conversation.

As we have seen, in the Arkisyn dataset, the content that se että is projecting can be 1) the main point of an ongoing telling, 2) an addition to the speaker's or other participants' earlier turn(s), or 3) a new or contrastive perspective to the conversation. In all the preceding cases, se että is used as a means of organizing the information shared in turns-at-talk. With se ettë, the speakers may signal to the interlocutors what they see as being worth emphasizing or crucial in regard to the ongoing speech situation. Se että can frame turns that affiliate with the preceding, but it is also used in contexts where, after conceding the point made in prior talk, the se että utterance brings up the speaker's contrastive or disaffiliating stance toward the matter at hand.

In the FinDia dataset, the usage of the se että construction is rather similar to that of Arkisyn. In the dialect interviews, too, se että often underlines the main point of the telling (within the frame of the narrative being told) or adds a new or contrasting point of view to the informant's own telling. In addition, also in the FinDia dataset, se että is used in organizing the course of interaction but it seems to have a quite a specific task, perhaps due to the monologic nature of the data: in these data, the construction emerges 
especially when the course of narration changes. This means that the se että expression, especially in the form of mut se että ('but SE ETTÄ'), is particularly commonly used when the informant introduces a new or a contrasting perspective to his or her story or brings the focus of the story back and returns to the main storyline after a sidetrack or a parenthesis.

In sum, when occurring TCU-initially, se että focuses the attention on what follows it as central to the interaction, underlining the upcoming content. This function is also reflected in the positions se että has in our data: it can be located in initial position in a turn, or in the middle of a lengthy, complex turn, but still in a TCU beginning. As is typical for projector phrases, the content that follows them might often be a complex stretch of talk that extends to several TCUs (Günthner 2011:24; Pekarek Doehler 2011:140). In such contexts, se että can point out the nucleus of the telling or the utterance and make it focal, while nominalizing the subsequent talk: se että frames the upcoming complex stretch of talk to be taken as a whole.

In fact, the Finnish se että expression shares several features with projector phrases identified in other languages. For example, when compared to the German phrase Die Sache ist 'the thing is' (Günthner 2011), both the Finnish se että and the German Die Sache ist project a continuation that is more relevant than the projector phrase itself; they focus the recipient's attention on the continuation; they prepare the recipients to align themselves 
to the upcoming information; and finally, they both often occur in argumentative contexts, and they may include features which already project disagreement or disaffiliation in the following turn by the se että turn's recipient (see e.g. examples (4 and 6). The English phrase The thing/fact is (see Aijmer 2007) also has some interactional similarities with the Finnish se että. According to Aijmer, The thing/fact is carries the rhetorical meaning of explanation or justification for a point of view (a cause or grounds for an opinion expressed in the preceding context). The thing/fact is can also be used to add a new argument, and when used with but, it can express opposition or rejection. All this also applies to the interactional characteristics of se että. Finally, also the French Il y a NP 'there is NP' and ce que/ce qui $X$, roughly 'what', initiating pseudocleft constructions (see Pekarek Doehler 2011) are similar to se että: they are used as sedimented formulae/formats which project more talk of a certain nature to come, and no longer function in clause combining but rather as routinized interactional projection practices.

Furthermore, an important feature that se että shares with projector phrases in other languages is that it contributes to recipient design by projecting the actional import of what is coming up (cf. Pekarek Doehler 2011). This is central to the emergence of se että as a projector phrase: as we have noted, it functions in support of intersubjectivity in preparing the addressee for the nature of the upcoming, also showing how it relates to what has been said 
just prior. In that way, the use of projector phrases helps recipients monitor the complex architecture of talk (Pekarek Doehler 2011:140; Günthner 2011:29).

\section{Prosodic features of se että}

In this section, we present our analysis of the prosodic delivery of se että in the Arkisyn corpus, carried out with the program Praat (Boersma and Weenink 2018). We show that, for the most part, se että forms one single prosodic word $^{14}$, which suggests that the expression is a rather fixed unit of its own. In $90 \%$ of our cases, the two elements in the expression, se and että, are prosodically latched together. In the cases where the elements are uttered separately (only $7 / 69$ cases $^{15}$ ), the expression and its context are also qualitatively different - i.e., these elements do not function as projector phrases in the way described in the sections above. The projector phrase se että always has one or two syllables only; it is never a trisyllabic se-et-tä, as would be expected on the basis of the canonical grammar. This shows prosodic erosion. In the latched-together se että cases, the stress (emphasis)

\footnotetext{
${ }^{14}$ By prosodic words we mean segments that form a tonal unit with one stressed syllable accompanied by unstressed syllable uttered under one tonal rhythmic pattern. These are the strong criteria for prosodic words. As weak criteria we used change in F0-curve, pause, and change in the waveform. (See Bruce 1998; Aho 2010.)

${ }^{15}$ Our Arkisyn collection includes 76 cases, but in 7 of them, the quality of the recording did not allow for the prosodic analysis. Consequently, only 69 cases are analyzed in this section.
} 
is always on the se element. This is also true for the cases where there is something preceding se et, such as mut se et 'but SE ET' and nimittäin se et 'namely SE ET'.

We did a further analysis on the cases where there is nothing intervening between $s e$ and $e t(t \ddot{a})$ and where the $s e$ element is in its nominative form (altogether 48 cases); that is, cases such as seki et (SE-CLT ET), se viel et (SE still ET) and sitä et (SE-PAR ET) were excluded from this examination. We found that there are four main variants (or, different pronunciations) of the expression, with two varying features: the length of the $e$-element and the presence of the final syllable tä in että. In the collection analyzed here, there are 36 long $e$ 's (seet, seettä) and 12 short $e$ 's (set, settä), and 26 cases without the syllable tä (seet, set) and 22 that have it (seettä, sett $\ddot{a})$. Altogether, the numbers of the different variants are 19 for seettä (see Figure 1 below), 17 for seet (see Figure 2 below), 9 for set (see Figure 3 below), and 3 for settä. Some of the cases thus involve rather strong prosodic erosion, most notably the set cases.

Figure 1: seettä (case no 1.1) 


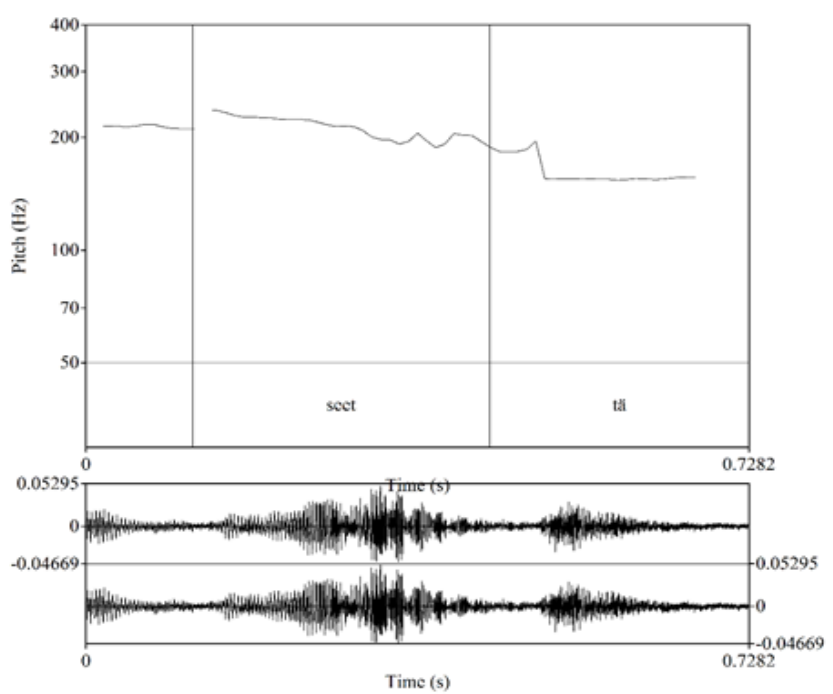

Figure 2: seet miks 'SE ET why' (case no 1.14)

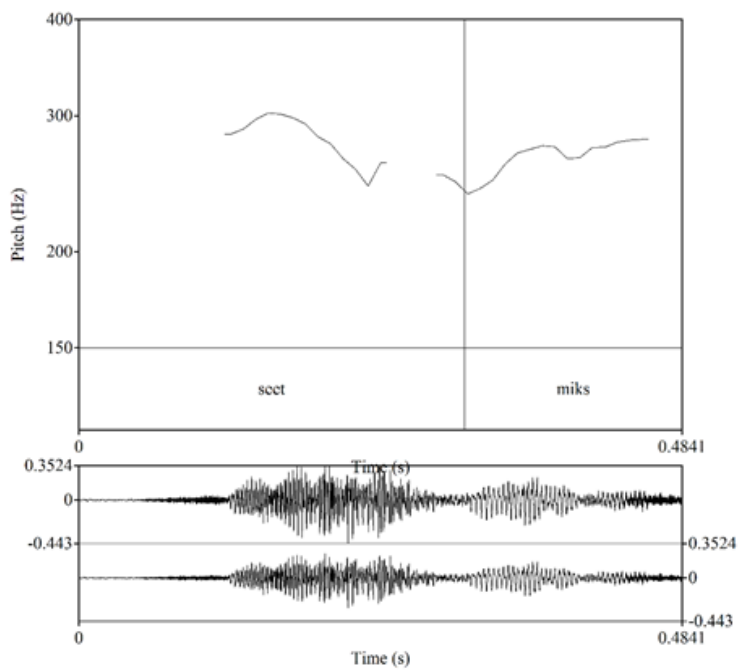

Figure 3: set (case no 2.48) 


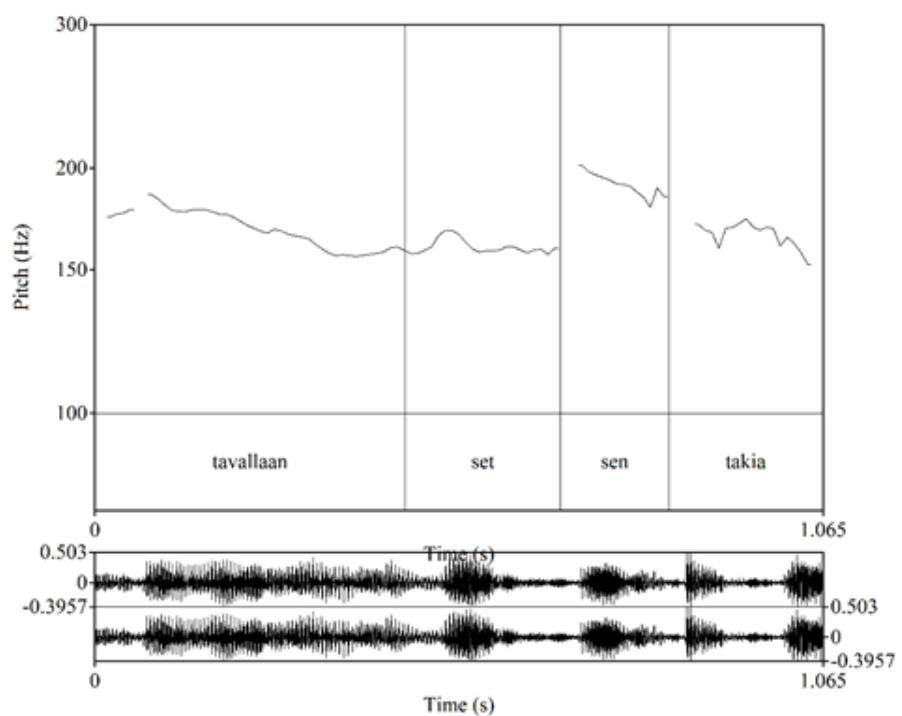

In other words, in terms of its prosody, given that the two elements form just one prosodic word and not two separable elements, se että seems to be a rather fixed unit or expression of its own prosodically as well. This suggests that the expression should perhaps be taken as a single item: seettä. This result attests to its fixedness resulting from frequent use (cf. Bybee 2010, Scheibman 2000).

\section{Conclusions}

In this chapter, we have focused on the Finnish se että expression occurring as an independent element in the beginning of a TCU. By examining the collocational, sequential, and (inter)actional environments in which se että 
occurs as well as by investigating the prosodic erosion of the expression, we have argued that se että is a fixed expression in terms of its form and functions, and suggested that it should be analyzed as a projector phrase with an important role in the sequential organization of turns-at-talk.

In our data, se että emerges as a fixed projective element in the talk-ininteraction both on its own and with collocating elements. These collocating elements - occurring in pre-, mid- and post-se että positions - might be particles, conjunctions, adverbials or other lexical items, or existential or other presentative clausal constructions se että functions as a part of. The preceding and intervening elements are to some degree formulaic as well and are connected with the actions and practices that se että is associated with. The content that follows se että can be the main point of an ongoing telling, an addition to earlier talk (manifested, e.g., as ja sit viel se että 'and then also SE ETTÄ' or seki että 'also SE ETTÄ'), or a new or contrastive perspective (manifested, e.g., as mut se että 'but SE ETTÄ'). In all these cases, se että (together with the collocating elements) is used as a means to organize the information in the turns-at-talk and to indicate the direction the speaker is going. We thus see se että as a projective device, pointing to the nature of the upcoming content, and argue that the contexts in which se että frequently occurs have contributed and contribute to what can be expected to occur after it, and thus have resulted in se että acquiring an interactional function that is more than the sum of its parts. 
Furthermore, the elements that occur in the post-se että position support our analysis that se että has lost at least some of its internal structure: in this expression, että no longer functions as a complementizer, witnessed by the fact that after se että the speakers often enough add another että, which then takes the role of complementizer in the ongoing structural unit.

As we have shown, the elements that co-occur with se että are not random but rather reflect the different facets of se että as an emergent device for routinized interactional projection practices; the collocating elements also manifest a degree of formulaicity arising from the uses that the fixed se että expression itself is put to in interaction. Se että is routinely used in certain sequential environments and has specific pragmatic functions. With se että, the speakers may direct the interlocutor(s) attention to what follows and thus underline the upcoming content as central to the ongoing interaction. The se että expression shares several features with projector phrases identified in other languages, and it functions in support of intersubjectivity in projecting more talk to come and preparing the addressee for the nature of the upcoming. The analysis of se että having grammaticized into a projector phrase is also supported by prosodic evidence; for the most part, se että forms one prosodic word where the two elements (se and $e t t \ddot{a})$ are latched together, and the stress is on se. Our analysis suggests that fixed expressions 
may gather around them even more formulaicity, as speakers routinely use them in certain contexts.

Our findings support the idea that se että emerges in interaction, with a rather fixed form of its own, yet sensitive to the current sequential context it is a part of. Rather than being generated by a syntactic rule involving a demonstrative integrated into a framing clause which then takes a complement clause as an argument, se että is a fixed unit which occurs TCU-initially as an independent element. In our data, se että functions as a modal fragment (Aijmer 2007) and a projector phrase (Günthner 2008, 2011; Pekarek Doehler 2011), stored and used as a whole.

\section{Data sources}

Arkisyn: A Morphosyntactically Coded Database of Conversational Finnish. Database compiled at the University of Turku, with material from the Conversation Analysis Archive at the University of Helsinki and the Syntax Archives at the University of Turku. Department of Finnish and Finno-Ugric Languages, University of Turku.

Corpus of Finnish Dialects. Syntax Archives, Department of Finnish and Finno-Ugric Studies, University of Turku. 


\section{References}

Aho, Eija. 2010. Spontaanin puheen prosodinen jaksottelu [The prosodic segmentation of spontaneous speech]. Helsinki: University of Helsinki.

Aijmer, Karin. 2007. "The Interface between Grammar and Discourse: The Fact Is That." In Connectives as Discourse Landmarks, ed. by Agnès Celle, and Ruth Huart, 54-72. Amsterdam: Benjamins.

Antaki, Charles, and Margaret Wetherell. 1999. "Show Concessions." Discourse Studies 1 (1): 7-27.

Auer, Peter. 2005. "Projection in Interaction and Projection in Grammar." Text \& Talk 25 (1): 7-36.

Auer, Peter, and Stefan Pfänder (eds). 2011. Constructions: Emerging and Emergent. Berlin: de Gruyter.

Boersma, Paul, and David Weenink. 2018. Praat: Doing Phonetics by Computer. Version 6.0.37, retrieved from http://www.praat.org/

Bruce, Gösta. 1998. Allmän och svensk prosodi. [General and Swedish prosody.] Praktisk lingvistik 16. Lund University: Institutionen för lingvistik.

Bybee, Joan. 2010. Language, Usage and Cognition. Cambridge: Cambridge University Press. 
Corrigan, Roberta, Edith Moravcsik, Hamid Ouali, and Kathleen Wheatley (eds). 2009. Formulaic Language. Amsterdam: Benjamins.

Couper-Kuhlen, Elizabeth, and Margret Selting. 2018. Interactional Linguistics: Studying Language in Social Interaction. Cambridge: Cambridge University Press.

Couper-Kuhlen, Elizabeth, and Sandra A. Thompson. 2000. "Concessive Patterns in Conversation.” In Cause - Condition - ConcessionContrast: Cognitive and Discourse Perspectives, ed. by Elizabeth Couper-Kuhlen, and Bernd Kortmann, 381-410. Berlin: Mouton de Gruyter.

Du Bois, John W., and Elise Kärkkäinen. 2012. "Taking a Stance on Emotion: Affect, Sequence, and Intersubjectivity in Dialogic Interaction.” Text \& Talk 32 (4): 433-451.

Duvallon, Outi, and Rea Peltola. 2017a. "Deontic Readings of the Imperative through the Prism of Force Dynamic Relations: Permissive and Preventive Utterances with the Discourse Marker vaa(n) in Finnish.” Journal of Pragmatics 120: 17-34.

Duvallon, Outi, and Rea Peltola. 2017b. "Voimadynaaminen VAAN: Odotusten, intentioiden ja kerrottavuuden partikkeli [Finnish VAAN: the force dynamic particle of expectations, intentions and tellability]." Virittäjä 121 (4): 500-533.

Erman, Britt, and Beatrice Warren. 2000. "The Idiom Principle and the Open Choice Principle.” Text 20 (1): 29-62. 
Fox, Barbara. 2007. "Principles Shaping Grammatical Practices.” Discourse Studies 9: 299-318.

Goodwin, Charles. 2002. "Time in Action.” Current Anthropology 43: 19-3.

Günthner, Susanne. 2008. “'Die Sache ist...': eine Projektorkonstruktion im gesprochenen Deutsch.” Zeitschrift für Sprachwissenschaft 27 (1): 3972.

Günthner, Susanne. 2011. "N be that-Constructions in Everyday German Conversation: A Reanalysis of 'die Sache ist/das Ding ist' ('the thing is')-Clauses as Projector Phrases. In Subordination in Conversation: A Cross-linguistic Perspective, ed. by Ryoko Suzuki, and Ritva Laury, 11-36. Amsterdam: Benjamins.

Hakulinen, Auli, and Mirja Saari. 1995. "Temporaalisesta adverbista partikkeliksi [From temporal adverb to discourse particle].” Virittäjä 99: 481-500.

Hakulinen, Auli. 2001. "On Some Uses of the Discourse Particle kyl(lä) in Finnish Conversation.” In Studies in Interactional Linguistics, ed. by Margaret Selting, and Elizabeth Couper-Kuhlen, 171-199. Amsterdam: Benjamins.

Hakulinen, Auli, Maria Vilkuna, Riitta Korhonen, Vesa Koivisto, Tarja Riitta Heinonen, and Irja Alho. 2004. Iso suomen kielioppi [Comprehensive grammar of Finnish]. Helsinki: Finnish Literature Society. 
Hopper, Paul. 1987. "Emergent grammar." Proceedings of the Thirteenth Annual Meeting of the Berkeley Linguistics Society 13: 139-157.

Hopper, Paul. 2011. "Emergent Grammar and Temporality in Interactional Linguistics." In Constructions: Emerging and Emergent, ed. by Peter Auer, and Stefan Pfänder, 22-44. Berlin: de Gruyter.

Hopper, Paul, and Sandra A. Thompson. 2008. "Projectability and Clause Combining in Interaction.” In Crosslinguistic studies of clause combining: the multifunctionality of conjunctions, ed. by Ritva Laury, 99-124. Amsterdam: Benjamins.

Kalliokoski, Jyrki. 1989. Ja. Rinnastus ja rinnastuskonjunktion käyttö ['And'. Coordination and the use of the coordinating conjunction]. Helsinki: Finnish Literature Society.

Koivisto, Aino, Ritva Laury, and Eeva-Leena Seppänen. 2011. "Syntactic and Actional Characteristics of the Finnish Että-Clause. In Subordination in Conversation: A cross-linguistic perspective, ed. by Ritva Laury, and Ryoko Suzuki, 69-102. Amsterdam: John Benjamins.

Kärkkäinen, Elise. 2009. "I thought It Was Pretty Neat: Social Action Formats for Taking a Stance.” In From 'Will' to 'Well'. Studies in Linguistics Offered to Anne-Marie Simon-Vandenbergen, ed. by Stef Slembrouck, Miriam Taverniers, and Mieke Van Herreweghe, 293304. Gent: Academia Press. 
Leino, Jaakko. 1999. "Mitä tarkoittaa se, että: Se-pronominista subjektina ja objektina toimivan että-lauseen yhteydessä [On using the pronoun se with an että clause as subject or object]." Virittäjä 103 (1): 27-51.

Lindström, Jan K., and Anne-Marie Londen. 2013. "Concession and Reassertion: on a Dialogic Discourse Pattern in Conversation.” Text \& Talk 33 (3), 331-352.

Niemi, Jarkko. 2015. Myönnyttelyn käytänteitä: Erimielisyys ja yhteisymmärryksen rakentaminen vuorovaikutuksessa [Practices of conceding: Disagreement and the negotiation of mutual understanding in conversation]. University of Helsinki, Faculty of Arts, Department of Finnish, Finno-Ugrian and Scandinavian Studies.

Nordlund, Taru. 2002. "Retention of Abstract Meaning: The Essive Case and the Grammaticalization of Polyphony in Finnish.” In New Reflections on Grammaticalization, ed. by Ilse Wischer, and Gabriele Diewald, 293-307. Amsterdam: Benjamins.

Nordlund, Taru. 2012. "Perustelevasta referoivaksi: Suomen partikkelin muka merkityksenmuutos 1800-luvun tekstiaineistojen valossa [From an explanatory particle to a marker of reported speech. The semantic shift of the Finnish particle muka; 'apparently, as if'].” Virittäjä 115 (4): $84-514$.

NS = Nykysuomen sanakirja [Dictionary of modern Finnish]. Helsinki: WSOY. 
Pawley, Andrew, and Frances Hodgetts Syder. 1983. "Two Puzzles for Linguistic Theory: Nativelike Selection and Nativelike Fluency. In Language and Communication, ed. by Jack J. C. Richards, and Richard R. W. Schmidt, 191-225. London: Longman.

Pekarek Doehler, Simona. 2011. "Clause-Combining and the Sequencing of Actions: Projector Constructions in French Talk-In-Interaction.” In Subordination in Conversation: A Cross-linguistic Perspective, ed. by Ryoko Suzuki, and Ritva Laury, 103-148. Amsterdam: Benjamins.

Sacks, Harvey. 1992. Lectures on Conversation. Ed. by Gail Jefferson. Cambridge: Blackwell Publishers.

Sacks, Harvey, Emanuel A. Schegloff, and Gail Jefferson. 1974. “A Simplest Systematics for the Organization of Turn-Taking for Conversation." Language 50: 696-735.

Salminen, Taru. 2000. Morfologiasta moniäänisyyteen: suomen kielen kvasirakenteen merkitys, käyttö ja kehitys [From morphology to polyphony: Meaning, function and evolution of the quasi-construction in Finnish]. Helsinki: Finnish Literature Society.

Scheibman, Joanne. 2000. "I dunno ... A Usage-Based Account of the Phonological Reduction of Don't in American English Conversation.” Journal of Pragmatics 32 (1): 105-124.

Schegloff, Emanuel. 1990. "On the Organization of Sequences as a Source of 'Coherence' in Talk-in-Interaction." In Conversational Organization 
and its Development, ed. by Bruce Dorval, 51-77. Norwood, New Jersey: Ablex.

Schegloff, Emanuel. 1996. “Turn Organization: One Intersection of Grammar and Interaction." In Interaction and grammar, ed. by Elinor Ochs, Emanuel A. Schegloff, and Sandra A. Thompson, 52-133. Cambridge: Cambridge University Press.

Schegloff, Emanuel. 2007. Sequence Organization in Interaction. A Primer in Conversation Analysis. Cambridge University Press.

Schiffrin, Deborah. 1987. Discourse Markers. Cambridge: Cambridge University Press.

Selting, Margret, and Elizabeth Couper-Kuhlen (eds). 2001. Studies in Interactional Linguistics. Amsterdam: John Benjamins.

Sidnell, Jack, and Tanya Stivers (eds). 2013. The Handbook of Conversation Analysis. Chichester: Wiley-Blackwell.

Siro, Paavo. 1968. "Suomen kielen että-lauseen ongelmasta." [Concerning the problem of the Finnish että clause.] In Fenno-Ugrica. Juhlakirja Lauri Postin kuusikymmenvuotispäiväksi 17.3.1968, 203-205.

Publications of the Finno-Ugrian Society 145. Helsinki: Finno-Ugrian Society.

Sorjonen, Marja-Leena. 1989. "Vuoronalkuiset konnektorit: mutta." In Suomalaisen keskustelun keinoja I, ed. by Auli Hakulinen, 162-176. Kieli 4. Helsinki: University of Helsinki, Department of Finnish. 
Sorjonen, Marja-Leena. 2001. Responding in Conversation: A Study of Response Particles in Finnish. Amsterdam: John Benjamins.

Suomalainen, Karita, Anna Vatanen, and Ritva Laury. 2016a. "Se että rakenne keskustelupuheessa: mihin sitä käytetään ja miten.” Paper given at the XLIII Kielitieteen päivät, Oulu, Finland, May 25-27.

Suomalainen, Karita, Anna Vatanen, and Ritva Laury. 2016b. "The Finnish se että as an emerging and emergent construction." Paper given at the Symposium on the emergence of units in social interaction University of Helsinki, August 4-5.

Suomalainen, Karita, Anna Vatanen, and Ritva Laury. In press. "The Finnish Se Että Initiated Expressions: NPs or not?” In The Structure and Pragmatics of the Noun Phrase across Languages: An Emergent Unit in Interaction, ed. by Sandra A. Thompson, and Tsuyoshi Ono. Amsterdam: John Benjamins.

Vilkuna, Maria. 1984. "Voiko -kin partikkelia ymmärtää? [Understanding conventional implicature: the clitic -kin/-kAAn in Finnish]." Virittäjä 88 (4): 393-407.

\section{Appendix}

Transcription symbols 


\begin{tabular}{|c|c|}
\hline , & level intonation \\
\hline$?$ & rising intonation \\
\hline$\uparrow$ & step up in pitch \\
\hline$\downarrow$ & step down in pitch \\
\hline spenak & emphasis \\
\hline$>$ speak $<$ & faster pace than in the surrounding talk \\
\hline$\langle$ speak $>$ & slower pace than in the surrounding talk \\
\hline${ }^{\circ}$ speak $^{\circ}$ & quiet talk \\
\hline sp- & word cut off \\
\hline spea:k & lengthening of a sound \\
\hline \#speak\# & creaky voice \\
\hline$£$ speak£ & smiley voice \\
\hline .h & audible inhalation \\
\hline $\mathrm{h}$ & audible exhalation \\
\hline speak & word spoken during inhalation \\
\hline[ & beginning of overlap \\
\hline ] & end of overlap \\
\hline$=$ & latching of units \\
\hline (.) & micropause (less than 0.2 seconds) \\
\hline$(0.6)$ & pause length in tenth of a second \\
\hline (speak) & item in doubt \\
\hline$(-)$ & item not heard \\
\hline
\end{tabular}


boldface focused item in the transcript 